Trikonomika

Volume 19, No. 2, December 2020, Page. 96-102

ISSN 1411-514X (print) / ISSN 2355-7737 (online)

\title{
WHY DO THE ELDERLY KEEP WORKING?
}

\author{
Sri Rekno Galuh Sitoresmi \\ Istiqomah \\ istiqomah@unsoed.ac.id \\ Sukiman \\ Universitas Jenderal Soedirman
}

Jl. Profesor DR. HR Boenyamin No.708, Banyumas, Jawa Tengah 53122

received: 19/8/20; revised: 18/9/20; approved: 14/12/20

\begin{abstract}
The elderly population are considered unproductive. However, in Kalisari village, many older people continue to work. This study aims to determine the effect of age, education level, number of dependents and other income on the elderly's decision to work. Primary data were collected using interview based on questionnaires. The population consists of 144 people aged $60+$ comprising of 84 people who are unemployed and 60 unemployed. In this study, the determination of the minimum sample size was carried out with the Slovin formula to choose 60 respondents consisting of 30 employed and 30 unemployed. Data analysis using binary logistic regression shows that age and education level do not have a significant effect on the elderly population's decision to work, while other income has a significant negative effect and the number of family dependents has a significant positive effect on the elderly's decision to work.
\end{abstract}

Keywords: human resource economics; labor force participation; population ageing; Kalisari village; binary logistic regression

\section{INTRODUCTION}

Elderly population is expected to increase rapidly in the future. For example, the proportion of population aged $60+$ increased from $10.33 \%$ in 2000 to $13.26 \%$ in 2010, and is projected to increase to $32.8 \%$ in 2050 (United Nations, 2010). The same trend of increasing proportion of older people was also observed in Vietnam (Long \& Ly, 2015). Based on BPS 2018 data, the proportion of elderly population in Indonesia was 9.28 percent, greater than the previous year of 8.97 percent. This shows that Indonesia has not been classified as a country with an old population structure because the elderly population has not reached 10 percent (Yanti \& Subidia, 2019). A country is categorized as having an old structure if the elderly population has reached 10 percent of the total population. However, in Indonesia there are several provinces where the elderly population is above 10 percent (Yanti \& Subidia, 2019) including Central Java. This is due to advances in the health sector which will have a positive impact on other fields (Takii \& Ramstetter, 2007). The phenomenon of aging population is characterized by the growth of the young population which continues to slow down due to a declining birth rate and an aging population that has increased due to an increase in life expectancy (Burtless,
2013). A better environment, advances in the economy and medical science has led to increased life expectancy (Utami \& Rustariyuni, 2013) and consequenltly results in the higher number of elderly population (Kartika \&Subidia, 2013).

The population ageing tends to reduce the rates of work participation and saving which are likely to have an adverse effect on economic growth (Marešová et al. 2015). Based on their modelling in Scotland, Lisenkova et al. (2013) conclude that population ageing is associated with lower output percapita and with higher public spending particularly on health and pension. Maestas et al. (2016) find that a 10\% increase in the proportion of the population aged $60+$ decreases the economic growth by $5.5 \%$. Two-thirds of the reduction is attributed to lower growth in the productivity of labor, one-third results from lower growth in labor force. However, the lower youth dependency rate, higher female work participation and older retirement age can reduce the negative effect (Bloom et al. 2010a; Bloom et al. 2010b). Moreover, population ageing provides economic opportunities for specialist products for the elderly, growing job opportunities in elderly's care, positive impact on tourism because affluent pensioners can travel anytime includingoff peak, care of grandchildren while parents work,reduced crime rate 
because older people tend to be more law obedient, and the benefit of higher knowledge and experience of an older workforce (Marešová et al. 2015).

The number of elderly people in the province of Central Java ranks second highest after D.I Yogyakarta. D.I Yogyakarta which ranks first is 13.81 percent, Central Java province ranks second at 12.59 percent, followed by East Java Province at 12.25 percent. The high percentage of the elderly population in the province of Central Java indirectly illustrates that the level of life expectancy (AHH) in the province of Central Java is relatively high. High life expectancy indicates an increasing quality of life in Central Java. Life expectancy that continues to increase shows the success of human development, but if it is not accompanied by an increase in quality, it will create a burden in development (Tanaya \&Yasa, 2015).

Life expectancy in Central Java Province tends to increase especially in Banyumas district which ranks seventh in Central Java. Life expectancy in Banyumas has increased during 2013-2018. The highest life expectancy was observed in 2018 (73.45) and is predicted to continue to increase or sustain on that figure based on data from the previous three years that remained at that figure. The composition of the population of Banyumas regency from 2013 to 2017 has increased including the fraction of population aged 60 years and over. The number of elderly population in 2016 was 216,900 people and experienced an increase in 2017 of 226,282 people.

In Banyumas district, the majority of the population worked in the trade sector and then followed by the industrial sector. In 2018 the proportion of population working in the trade sector was $25.86 \%$ and the industrial sector $18.83 \%$, greater than the agricultural sector which was $17.28 \%$. One of the contributors to employment in the manufacturing sector in Banyumas Regency is the village of Kalisari, Cilongok District, Banyumas Regency which is famous for its tofu industry. Most of the Kalisari community work as tofu processors and traders, and they come from various ages. Based on data from the village government of Kalisari, the majority of the population relies on tofu industry. The Kalisari Village tofu industry became famous since 1965 and its development increased rapidly from 198 units in 2013 to 251 units in 2019. Kalisari tofu processing industry is able to absorb a lot of labor, not only the productive age population but also the older people. The total employment in the tofu industry is about 500 persons, of which one-fourths are the older people.

This paper aims to analyze the determinants of the decision of the older people to keep working in the industry. The independent variables being studied consist of age, education, number of dependents, and other income. The contribution of this paper to the existing literature lies in the selection of research location where rural industry grows rapidly employing quite a lot of older people. The practical benefit of this setting is that it will contribute to the policy options of rural industrialization in dealing with the problem of population ageing. The theoretical contribution of this study is the inclusion of other income in the model. While other studies focus on pension as the independent variable, this study uses other income which covers a broad range of cash as well as any in-kind aid such as pension, support from children or other family members and transfer from government.

Affandi (2009) argues that an increase in the elderly population is an interesting issue to discuss because in general the elderly rely on the productive age population or the so-called dependency ratio. Dependency ratio is the ratio between the productive age population and the non productive age population. The burden on the productive age population is getting greater along with the increasing number of elderly population.

Yanti \& Subidia (2019) argue that there are at least three reasons underlying why the elderly are still working including the large number of elderly people who are still physically and mentally strong, there is economic pressure that requires the elderly to continue working, and the last is self-actualization or emotional motives. Marital status could be another reason. Rimbawan (2008)said that the majority of elderly women are divorced, while the elderly male partners are married. In Indonesia, husbands are to make a living so that divorced women lose their life support, causing them to have to continue working to support themselves (Utami \& Rustariyuni, 2016). In addition, another factor that can also influence the elderly to continue working is the level of education. Elderly people who have a high educational background, generally have a good job so that in their old age they no longer need to find work to support themselves and their families (Affandi,2009). On the one hand, those with higher education backgrounds generally work in the formal sector and get pension benefits. On the other hand, the elderly who have a low educational history still have to work to support their needs (Utami \& Rustariyuni, 2016). In Sweden, the total proportion of individuals aged 55-64 in the workforce increased between 2004 and 2011, but the increase was mostly in professions with lower educational requirements, a lower salary and dominated by women (Nilsson et al.2016).

The relationship between the independent and dependent variables which leads to the hypotheses is presented in the following paragraphs. Old age has diminished the physical abilities of the elderly (Utami \& Rustariyuni, 2016). Ling \&Fernandez, (2010) find that age has a negative effect on labor participation. Long \& Ly (2015) find that age is negatively associated with the elderly's decision to work, since they are more vulnerable to health problems. These finding is supported by Utami \& Rustariyuni (2016) because 
with increasing age, a person's ability to carry out daily activities decreases.

Affandi (2009), Ling \& Fernandez (2010) and Junaedi et al. (2017) argue that the level of education influences the work participation of the elderly population. Affandi finds that the higher the level of education of the elderly, the percentage of working elderly tends to decrease. Elderly who have a high educational background generally used to have a good job and get pension, so that in their old age they no longer need to work to meet their needs and their families.

Utami \& Rustariyuni (2016) state that elderly residents who have families usually have dependents on their families, such as children and grandchildren. They conclude that the number of dependents has a positive effect on the decision of the elderly population to keep working. When the number of dependents increases, the possibility of the elderly to keep working also increases because living needs also increase. In Hongkong those living with married children have the lowest labor force participation, but living with unmarried children, sons in particular, increases the likelihood of elderly employment (Tong et al. 2018).

In developing countries many elderly people do not qualify for pensions. In rural areas the probability of receiving pensions is even lower, thus increasing the work participation of the elderly (Juarez \& Pfutze, 2015). Due to the absence of pensions, own income as laborers and financial transfers from adult children become sources of livelihood for seniors in China (Cai et al. 2012). Reddy (2016) finds that the elderly having relatively poor socio-economic status have a higher probability to participate in the labor force. This finding is in line with Kartika \& Subidia (2014) who state that the elderly who have low income are more likely to continue working compared to the elderly who have high income.

\section{METHODS}

The design of this study is quantitative research to analyze the effect of age, education, number of dependents, and other income on the decision of the elderly to work. This research took place in JanuaryFebruary 2020 in the village of Kalisari, Cilongok, Banyumas Regency. Primary data were collected through interview techniques based on questionnaires.

The decision of the elderly to work is measured in dummy variable, namely the elderly who worksis given a value of one (1) and the elderly who does not work iszero (0). Age is the age of the elderly population at the time of the interview and is measured in years. Education level is elderly education which refers to formal education and is measured in years. Number of dependents is the number of all members in a family that are still the responsibility of the respondent and is measured in number of persons. Other income is a person's income besides wages. Other income sources include transfer from government, financial assistance from relatives and so on. This income is measured in rupiah per month.

The population in this study were all residents who were more than 60 years old who live in the village of Kalisari, Cilongok sub-district. The total elderly population in the village of Kalisari is 144 people consisting of 84 people working and 60 unemployed. In this study, the determination of the minimum sample size was carried out with the Slovin formula of 60 people consisting of 30 elderly residents who worked and 30 elderly residents who did not work. The respondents were selected by random sampling technique from each group. Randomization was performed with the Microsoft Office Excel program trough the randbetween menu.

The analytical method used in this study is logistic regression. This study analyzes the effect of age, education, number of dependents, and other income on the decision of the elderly to work with the following model:

$\mathrm{ED}_{\mathrm{i}}=\mathrm{L}_{\mathrm{n}}\left[\frac{\hat{P}}{1-\hat{P}}\right]=\beta_{0}+\beta_{1} A G E+\beta_{2} E D U+\beta_{3} D E P+\beta_{4} I N C+\mu_{i}$

where :

$\mathrm{ED}_{\mathrm{i}} \quad=$ Elderly's decision to work

$\mathrm{L}_{\mathrm{n}} \quad=$ Natural logarithm

$\mathrm{p}^{\wedge} \quad=$ Probability of the elderly people to work

1-p^ $=$ Probability of the elderly people not to work

B0 $=$ Constant

$\beta_{1}, \beta_{2}, \beta_{3}, \beta_{4}=$ Regression coefficients

$\mathrm{AGE}=$ Age

EDU = Education

DEP = Number of dependents

INC $=$ Other income

$\mu_{\mathrm{i}} \quad=$ Error Terms

Testing the suitability of the model is done by -2loglikelihood and omnibus tests. This test is carried out to determine whether the independent variables entered into the model are significantly fit or not (Ghozali, 2012: 341). This test is done by comparing with the Chi-Square value. The requirement for this test is that the value of -2loglikelihood must be smaller than the Chi-Square value. If the value of -2loglikelihood is smaller than the value of Ci-Square, then the model is fit with the data and feasible to use, but if the value of $-2 \log$ likelihood is greater than the value of Ci-Square, then the model is not fit with the data.

Omnibus testing is performed to compare models before and after the independent variables are entered. Omnibus test is the difference between the value of -2loglikelihood before the independent variable is entered with the value of -2loglikelihood after the independent variable is entered. This study uses the Nagelkerke R Square test, and was conducted to 
determine the magnitude of the independent variables in explaining the dependent variable. Hosmer and Lemeshow test is performed to compare predictions from logistic regression models with observational data or test the null hypothesis that empirical data matches the model, in other words there is no difference between the model and the data so that the model is fit or feasible to use.

The Wald test in logistic regression is used to find out whether the independent variables have a significant effect on the dependent variable. Wald test is done by comparing the significance value or P-value with an alpha value of 0.05 . If the significance value is smaller than alpha of 0.05 ( $\mathrm{P}$-value $<0.05)$ then $\mathrm{H} 0$ is rejected.

\section{RESULTS}

This section explains the description of respondents and the results of data analysis. Descriptions of respondents by age, education, number of dependents and other income are shown at Table 1.

Based on Table 1, the age group of 60-69 years is dominated by the working elderly population. The age group of 70-90+ years is dominated by elderly people who do not work. Thus it can be concluded that the older a person is, the lower the probability to work. Table 2 presents the distribution of respondents by education. It shows that the number of elderly population with primary school education is more dominant than other levels of education.

Dependents are people whose needs are still financed, such as wife, children and others. The elderly should no longer have to bear dependents given their age. But in reality, there are elderly people who have to bear the living needs of their children and even grandchildren. Table 3 presents the number of elderly people who still have dependents by work status and age.

The data shows that half of the respondents in this study have dependents. The elderly who have dependents are dominated by those who work, namely 24 consisting of 17 elderly at the age of 60-69 years and 7 elderly withinthe age range of 70-79 years. As for the elderly who do not work, the number of those who still have dependents is only 6 persons: 3 persons in the age range 60-69 years and one person in the age range 70-79 years, $80-89$ years and $90+$, respectively.

Other income is income that is obtained not from main income, such as from side jobs, transfer from the government and support from their children and relatives. Table 4 shows the distribution of the elderly who have other income by work status and age.

Based on Table 4, the number of elderly respondents who have other income is dominated by elderly people who do not work. The income comes from their family, such as children, nephews or relatives. The assistance can be in the form of basic needs or cash, but there are also elderly who get support from the government.
Elderly who do not work but have other income is dominated by those within the age range of 70-79 years (11 persons) and followed by elderly within age range of 80-89 years ( 9 persons). There are 7 persons in the age range 60-69 years who receive other income and 1 person at age $90+$. In the elderly group who work there are only 6 elderly people who have other income, consisting of 4 people in the age range 70-79 years and 2 people in the age range 60-69 years. The other income comes from their side jobs and assistance from the government.

The value of -2loglikelihood always decreases from 39.595 to 30.307 while the Chi Square value is 73.311. The logistical value of 30.311 is smaller than the Chi Square value of 73.311, making it fit with the data. Omnibus tests are used to compare models before independent variables are entered into the model with -2loglikelood after the independent variables are entered into the model. The value of $-2 \log$ likehood before the independent variable entered was 83.178 and the value of -2loglikelihood after entering the independent variable was 30.307 so the difference between the two was 52.870 with a degree of freedom of 4 and it was significant implying that the model used was right for the next analysis.

In this study, the Negelkerke R Square test was used. Negelkerke R Square value is 0.781 , meaning that the independent variables can explain the variation of the dependent variable by 78.1 percent. The value of Hosmer and Lemeshow was 3.368 with a degree of freedom of 8 and p-value of $0.909>$ alpha 0.05 , which means the model fit with the data.

Wald test is used to determine whether the independent variables significantly influence the dependent variable. The Wald test results are shown in Table 5 .

Table 5 shows that age and education level do not significantly influence the elderly's decision to work. Number of dependents has a significant positive effect on the decision of the elderly to work and other income has a significant negative effect on the decision of the elderly to work.

\section{DISCUSSION}

The analysis shows that age does not have a significant influence on the decision of the elderly to work. This finding contradicts Ling \& Fernandez (2010), Long \& Ly (2015) and Utami \& Rustariyuni (2016) who conclude that age negatively influences a person's decision to continue working. This might be due to the fact that the location of the tofu industry where the elderly work is close to their homes. So, they do not need to travel long to get to their working site. Moreover, working in the tofu industry does not consume too much energy. In addition there are also elderly who continue to work with the motivation to 
spend time and meet friends. As long as they are in good health status, they enjoy to work.

Level of education has no significant effect on the decision of the elderly to work. This does not support the findings of Affandi (2009), Ling \&Fernandez, (2010) and Junaedi et al. (2017) that the level of education negatively influences the supply of elderly workers. This seems to be due to the lack of data variation because most respondents have low education, mostly only completed primary school. In addition, the tofu industry which is the source of income for the elderly does not require a minimum education.

The number of family dependents has a significant positive effect on the decision of the elderly to work. The elderly continue to work in order to meet the needs of themselves and their dependents. This finding supports Affandi (2009) who argues that the large number of elderly people who still work means that the elderly can still support themselves. In fact, the elderly still support their children who live with them. This finding also supports Utami \& Rustariyuni (2016) who conclude that the number of dependents positively influences the decision of the elderly to keep working. In Hongkong those living with married children have the lowest labor force participation, but living with unmarried children, sons in particular, increases the likelihood of elderly employment (Tong et al. 2018).

Other income has a significant effect on the decision of the elderly to work. Other income can be in the form of pension, transfer from the government and support from relatives. This means that the higher the level of other income, the less likely the elderly to work. This is because the other income allows the elderly to fulfill their daily needs. When the elderly do not receive other income, they still work to meet their needs. In developing countries many elderly people do not qualify for pensions. In rural areas the probability of receiving pensions is even lower, thus increasing the work participation of the elderly (Juarez \& Pfutze, 2015). Chanda \& Mishra (2019) and Reddy (2016) conclude that elderly work participation in India results from financial deprivations and lack of support. Kartika $\&$ Subidia (2014) state that one of the factors that influence the elderly to keep working is the economic factor; elderly who have low economic status requires them to keep working. Due to the absence of pensions, own income as laborers and financial transfers from adult children become sources of livelihood for seniors in China (Cai et al.,2012). One solution is to develop a pension program for the elderly. But unfortunately it has not succeeded in reducing the labor force participation of the elderly in China (Ning et al.,2016; Gao \& Feng, 2020). Cash transfers in rural Mexico for seniors (aged 70 years and over) reduce the labor force participation of male seniors, especially those who live alone and are relatively poor, but have less impact on female seniors. The program has a negative effect on the labor force participation of boys aged 12-17 years, but has no effect on girls of the same age (Juarez \& Pfutze, 2015).

In dealing with the consequences of population ageing, the policy options includethe promotion of immigration, labour force participation of the elderly (Temple \& McDonald, 2017) and the increase in pension entitlement age. Other policy responses include higher retirement savings, higher accumulation of human capital, alternate pension funding plans and immigration (Blomm et al. 2010b).

Labor force participation of the elderly will be a solution to population ageing (Temple \& McDonald, 2017). Ladusingh \& Thangjam (2017) found that work participation of mature age in India increased from $13.3 \%$ in $2004-05$ to $16.4 \%$ in $2011-12$. The growth in elderly labor force participation in Australia has led to large increases in the elderly income in Australian (Temple et al. 2017). However, the participation could be impeded by such barriers as age discrimination, the challenge of retraining and reskilling, and availability of flexible workplace due to health problems (Temple $\&$ McDonald, 2017). Therefore, government policies should be targeted to remove these barriers. Moreover, the government should provide incentives for the employers hiring the elderly people such as a subsidy or tax deduction, and regulations on anti age-discriminative minimum wage and social insurance programs. Furthermore, self-employment among the mature age should also be promoted with such supports as financial as well as non-financial aids (Long \& Ly, 2015).

\section{CONCLUSIONS}

This study finds that age and education level do not influence the elderly's decision to work, the number of dependents has a significant positive effect, and other income has a significant negative effect on the decision of the elderly to work. The driving forces of the elderly to keep working are indeed more due to economic motives because there are dependents and lack of financial support. An interesting result of this study is that rural food processing industry, in this case the tofu industry in the village of Kalisari is able to become a labor absorber for the elderly, thus becoming a solution for population ageing in the village and surrounding areas.

The finding that education does not have a significant effect on the decision of the elderly to work is due to the lack of data variation because most respondents only completed primary school. Therefore further research examining the relationship between the two variables needs to consider the diversity of respondents' educational backgrounds. The Negelkerke R Square value is 0.781 , meaning that the independent variables can explain the variation of the dependent variable by 78.1 percent. Further studies are recommended to include other independent variables. 


\section{REFERENCES}

Affandi, M. 2009. Faktor-Faktor yang Mempengaruhi Penduduk Lanjut Usia Memilih untukBekerja. Journal of Indonesian Applied Economics, 3(2), 99-110.

Bloom, D. E., Canning, D., \& Fink, G. 2010. Implications of Population Ageing for Economic Growth. Oxford Review of Economic Policy, 26(4), 583-612.

Bloom, D. E., Canning, D., \& Fink, G. 2010. The Greying of the Global Population and Its Macroeconomic Consequences. Twenty-First Century Society, 5(3), 233-242.

Burtless, G. 2013. The impact of population aging and delayed retirement on workforce productivity Center for Retirement Research at Boston College Working Paper No. 2013-11.

Cai, F., Giles, J., O’Keefe, P., \&Wang, D-W. 2012. Old-Age Support in Rural China: Challenges and Prospects. Washington, DC: World Bank, Directions in Development.

Chanda, S., \& Mishra, R. 2019. Impact of Transition in Work Status and Social Participation on Cognitive Performance Among Elderly in India. BMC Geriatrics, 19(1), 1-10.

Gao, X., \& Feng, T. 2020. Public Pension, Labor Force Participation, and Depressive Symptoms across Gender among Older Adults in Rural China: A Moderated Mediation Analysis. International Journal of Environmental Research and Public Health, 17(9), 3193.

Ghozali, I. 2012. Aplikasi Analisis Multivariate dengan program IBM SPSS.Semarang: BP Universitas Diponegoro.

Juarez, L., \& Pfutze, T. 2015. The Effects of a Noncontributory Pension Program on Labor Force Participation: The Case of 70 y Más in Mexico. Economic Development and Cultural Change, 63(4), 685-713.

Junaedi, J., Erfit, E.\& Prihanto, P. H. 2017. Faktor-faktor Sosial Ekonomi yang Mempengaruhi Keterlibatan Penduduk Lanjut Usia dalam Pasar Kerja di Provinsi Jambi. E-Jurnal Ekonomi Pembangunan Universitas Udayana, 3(2), 197-205.

Kartika, N.P.R.D, \& Subidia, I. K. 2014. Pengaruh Variabel Sosial Demografi dan Sosial Ekonomi terhadap Partisipasi Kerja Penduduk Lanjut Usia. E-Jurnal Ekonomi Pembangunan Universitas Udayana, 3(6), 247-256.

Ladusingh, L., \& Thangjam, M. 2017. Gender Differential in Occupation and Income among the Elderly in India. Ageing International, 43(2), 174-189.

Ling, G.S. \& Fernandez, J.L. 2010. Labour Force Participation of Elderly Persons in Penang. Paper presented at the International Conference on Business and Economic Research Sarawak, Malaysia 15 -16 March 2010.

Lisenkova, K., Mérette, M., \& Wright, R. 2013.
Population Ageing and the Labour Market: Modelling Size and Age-specific Effects. Economic Modelling, 35, 981-989.

Long, G.T \& Ly, L.T. 2015. Determinants of Labor Force Participation of Older People in Vietnam. Journal of Economics and Development, 17(2), 28-52.

Maestas, N., Mullen, K.J., \&Powell, D. 2016. The effect of population aging on economic growth, the labor force and productivity. NBER Working Paper No. 22452.

Marešová, P., Mohelská, H., \& Kuča, K. 2015. Economics Aspects of Ageing Population. Procedia Economics and Finance, 23, 534-538.

Nilsson, K., Östergren, P.-O., Kadefors, R., \& Albin, M. 2016. Has the Participation of Older Employees in the Workforce Increased? Study of the Total Swedish Population Regarding Exit from Working Life. Scandinavian Journal of Public Health, 44(5), 506-516.

Ning, M., Gong, J., Zheng, X., \& Zhuang, J. 2016. Does New Rural Pension Scheme decrease elderly labor supply? Evidence from CHARLS. China Economic Review, 41, 315-330.

Reddy, A. B. 2016. Labour Force Participation of Elderly in India: Patterns and Determinants. International Journal of Social Economics, 43(5), 502-516.

Rimbawan, N. D. 2008. Profil Lansia di Bali dan Kaitanya dengan Pembangunan (Deskripsi Berdasarkan Hasil Supas 2005 dan Sakernas 2007). PIRAMIDA: Jurnal Kependudukan dan Pengembangan Sumberdaya Manusia, 4(2), 1-11.

Takii, S., \& Ramstetter, E. D. 2007. Survey of Recent Developments.Bulletin of Indonesian Economic Studies, 43(3), 295-322.

Tanaya, A. R., \& Yasa, I. G. 2015. Kesejahteraan Lansia dan Beberapa Faktor yang Mempengaruhi Di Desa Dangin Puri Kauh. PIRAMIDA: Jurnal Kependudukaan dan Pengembangan Sumberdaya Manusia, 11(1), 8-12.

Temple, J. B., Rice, J. M., \& McDonald, P. F. 2017. Mature Age Labour Force Participation and the Life Cycle Deficit in Australia: 1981-82 to 2009-10. The Journal of the Economics of Ageing, 10, 21-33.

Temple, J. B., \& McDonald, P. F. 2017. Population Ageing and the Labour Force: 2000-2015 and 2015-2030. Australasian Journal on Ageing, 36(4), 264-270.

Tong, Y., Chen, F., \& Su, W. 2018. Living Arrangements and Older People's Labor Force Participation in Hong Kong, 1986-2016. Social Science \& Medicine, 229, 50-59.

United Nations. 2010. World population ageing 2009. New York: the United Nations, Department of Economic and Social Affairs, Population Division.

Utami, N. P., \& Rustariyuni, S. D. 2016. Pengaruh Variabel Sosial Demografi terhadap Keputusan Penduduk Lanjut Usia Memilih Bekerja di Kecamatan Kediri. Jurnal Ekonomi Kuantitatif Terapan, 9(2), 135-141. 
Table 1. Distribution of Respondents by Age

\begin{tabular}{lccccc}
\hline \multicolumn{1}{c}{$\begin{array}{c}\text { Respondent's } \\
\text { Decision }\end{array}$} & \multicolumn{5}{c}{ Age (years) } \\
\cline { 2 - 5 } Total \\
\hline Work & $60-69$ & $70-79$ & $80-89$ & $90+$ & \\
Does not work & 9 & 9 & 0 & 0 & 30 \\
\hline Total & 30 & 20 & 9 & 1 & 60 \\
\hline
\end{tabular}

Table 2. Distribution of Respondents by Education

\begin{tabular}{lcccccc}
\hline & \multicolumn{6}{c}{ Education } \\
\cline { 2 - 6 } $\begin{array}{c}\text { Respondent's } \\
\text { Decision }\end{array}$ & $\begin{array}{c}\text { Do not } \\
\text { complete } \\
\text { primary } \\
\text { school }\end{array}$ & $\begin{array}{c}\text { Primary } \\
\text { school }\end{array}$ & $\begin{array}{c}\text { Junior } \\
\text { high } \\
\text { school }\end{array}$ & $\begin{array}{c}\text { Senior } \\
\text { high } \\
\text { school }\end{array}$ & $\begin{array}{c}\text { Univ- } \\
\text { ersity }\end{array}$ & Total \\
\hline Work & 0 & 25 & 4 & 1 & 0 & 30 \\
Does not work & 7 & 23 & 0 & 0 & 0 & 30 \\
\hline Total & 7 & 48 & 4 & 1 & 0 & 60 \\
\hline
\end{tabular}

Table 3. Respondents with Dependents

\begin{tabular}{cccc}
\hline \multicolumn{4}{c}{ Respondent's Decision } \\
\hline \multicolumn{3}{c}{ Work } & \multicolumn{2}{c}{ Does not work } \\
\hline Age (years) & Frequency & Age (years) & Frequency \\
\hline $60-69$ & 17 & $60-69$ & 3 \\
$70-79$ & 7 & $70-79$ & 1 \\
$80-89$ & 0 & $80-89$ & 1 \\
$90+$ & 0 & $90+$ & 1 \\
\hline Total & 24 & Total & 6 \\
\hline
\end{tabular}

Table 4. Distribution of Respondents Having Other Income By Work Status and Age

\begin{tabular}{ccc}
\hline Age (years) & Working Elderly & Non-working Elderly \\
\hline $60-69$ & 2 & 7 \\
$70-79$ & 4 & 11 \\
$80-89$ & 0 & 9 \\
$90+$ & 0 & 1 \\
\hline Total & 6 & 28 \\
\hline
\end{tabular}

Table 5. Results of Wald Test

\begin{tabular}{lrrrrrr}
\hline & \multicolumn{1}{c}{ B } & \multicolumn{1}{c}{ S.E } & Wald & Df & Sig. & Exp(B) \\
\hline AGE & -0.086 & 0.069 & 1.545 & 1 & 0.214 & 0.918 \\
EDU & 5.675 & 2338.264 & 0.000 & 1 & 0.998 & 291.420 \\
DEP & 2.183 & 0.924 & 5.576 & 1 & 0.018 & 8.872 \\
INC & -0.803 & 0.331 & 5.892 & 1 & 0.015 & 0.448 \\
Constant & -27.834 & 14029.585 & 0.000 & 1 & 0.998 & 0.000 \\
\hline
\end{tabular}

Source: Output of IBM SPSS Statistics 23 